\begin{tabular}{|c|c|}
\hline Nuansa Journal of Arts and Design & NUANSA \\
\hline Volume 5 Nomor 1 April 2021 & \\
\hline e-ISSN: 2597-405X dan p-ISSN: 2597-4041 & ㅁ \\
\hline (c) (1) This work is licensed under a Creative Commons Attribution & \\
\hline
\end{tabular}

\title{
Upaya Meningkatkan Keterampilan Menari Siswa Kelas VIII E di SMP 4 Bulukumba Melalui Penerapan Metode Think Pair Share
}

\section{Selfiana Saenal \\ Penulis}

\author{
Keywords : \\ Keterampilan; \\ Menari; \\ Metode Think Pair Share;
}

\section{Corespondensi Author}

PPs Universitas Negeri Makassar

Email:sefianasaenal@unm.ac.id

\begin{abstract}
ABSTRAK
Penelitian ini bertujuan untuk menjawab permasalahan tentang bagaimana Upayah Meningkatkan Keterampilan Menari Siswa Kelas VIII E di SMP 4 Bulukumba Melalui Penerapan Metode Think Pair Share. Metode vang digunakan adalah metode Kualitatif yaitu gambaran objek penelitian secara langsung dan dengan teknik data yaitu sasaran dan sampel, observasi, wawancara dan dokumentasi, dan juga menggunakan metode Kuantitatif yaitu mengukur tingkat keterampilan dan dengan tes unjuk kerja untuk melakukan penilaian dengan menggunakan aspek penilaian yaitu wiraga, wirama dan wirasa. Pada penelitian ini dilakukan sebanyak 2 siklus, pada siklus I dilakukan sebanyak 4 kali pertemuan sampai siswa menunjukan hasil keterampilannya dengan kelompok masing-masing, namun pada siklus I siswa belum percaya diri dalam mengemukakan keterampilannya dalam menari, sehingga pada siklus I perlu adanya perbaikan pada tahap siklus II. Pada siklus I siswa mampu menerima pembelajaran seni budaya dengan baik namun kurang percaya diri terhadap siswa untuk tampil menari dan pada tahap siklus II keterampilan siswa mulai meningkat. Perolehan pada siklus I dengan nilai rata-rata 72,8 dan mengalami peningkatan siklus II dengan jumlah perolehan nilai rata-rata sebanyak 92,3.
\end{abstract}

\section{PENDAHULUAN}

Pada saat ini banyak siswa yang mengalami kesulitan dalam belajar seni tari. Hal ini berarti perlu adanya upaya-upaya dalam mengatasi kesulitan belajar seni tari tersebut. Upaya-upaya tersebut telah banyak dilakukan, seperti memperhatikan penyebab kesulitan belajar tersebut, baik yang bersumber dari dalam siswa itu sendiri, seperti kurangnya minat siswa pada pembelajaran seni tari. Keadaan ini menuntut guru untuk melakukan pembelajaran dengan cara yang tepat dan efektif. Guru dituntut tidak hanya menyampaikan materi secara tuntas, tetapt juga dituntut untuk dapat 
melakukan perubahan pada diri siswa yang belajar.

Pada mata pelajaran Seni Budaya yang sebagian besar materinya berisi praktek, berdasarkan observasi yang peneliti amati metode yang digunakan oleh guru adalah metode ceramah. Guru dalam melaksanakan pembelajaran Seni Budaya menularkan pengetahuan dan informasi dengan menggunakan lisan. Dari hal ini dapat dilihat bahwa keaktifan siswa kurang berperan, sehingga untuk berpikir kreatif pun siswa mengalami hambatan, selain itu metode ceramah ini menimbulkan rasa bosan pada siswa, sehingga metode ini dirasa kurang efektif. Oleh karena itu dalam proses belajar mengajar perlu adanya pendekatan pembelajaran yang lebih efektif mampu menciptakan suasana lebih aktif siswa khususnya pada mata pelajaran Seni Budaya,

Pembelajaran seharusnya menjadi aktivitas yang terkait dengan kemampuan untuk mengaktualisasikan seluruh kemampuan sumber daya, bukan sebaliknya. Tugas dan tanggung jawab guru bukan sekedar mendidik siswa agar memiliki kepribadian yang baik tetapi juga harus mendidik dan membimbing siswa dalam hal kreativitas belajar agar prestasi belajarnya dapat meningkat. Dalam proses belajar mengajar sesuai dengan perkembangannya guru tidak hanya berperan untuk memberika informasi terhadap siswa, tetapi lebih jauh guru dapat berperan sebagai perencana, pengatur, dan pendorong siswa agar dapat belajar secara efektif dan peran berikutnya adalah dari keseluruhan proses belajar mengajar.

Guru harus mampu menciptakan suasana belajar yang dapat meningkatkan motivasi siswa untuk turut aktif dalam kegiatan pembelajaran. Proses belajar berlangsung dengan adanya interaksi timbal balik antara guru dan siswa. Pelaksanaan Metode think pair share (TPS) dibutuhkan kemauan dan kemampuan serta kreatifitas guru dalam lingkungan kelas. Sehingga dengan

Metode think pair share (TPS) memberikan waktu kepada para siswa untuk berpikir dan merespon serta saling bantu satu sama lain. Metode think pair share (TPS) memberi siswa kesempatan untuk bekerja sendiri dan bekerja sama dengan orang lain. Untuk meningkatakan menggunakan metode ini guru bukannya pasif, tapi harus lebih aktif terutama saat menyusun rencana pembelajaran secara matang. pengaturan kelas saat pelaksanaan, dan membuat tugas untuk dikerjakan siswa bersama kelompok

Berdasarkan hasil Observasi guru Seni Budaya kelas VIII E di SMP Negeri 4 Bulukmba diperoleh keterangan bahwa: Saya sebagai guru Seni Budaya melihat kecenderungan hasil belajar siswa khususnya Keterampilan menari kelas VIII E pada pelajaran Seni Budaya. Pada proses pembelajaran di kelas, kemampuan siswa untuk bertanya atau meminta bantuan dari guru masih kurang. Siswa malas untuk bertanya bila diberi pertanyaan oleh guru, hanya sedikit yang menjawab. Dengan kata-kata lain, proses pembelajaran didominasi oleh guru, siswa hanya datang melalui kunjungan, bahkan jarang ada pertanyaan dari siswa. Hal ini menunjukan siswa kurang aktif dalam proses pembelajaran. Dilihat dari keadaan di atas maka metode yang di gunakan masih kurang baik sehingga terlihat aktifitas guru lebih banyak dari aktivitas siswa dalam proses pembelajaran.

Mengatasi hal tersebut guru dituntut menggunakan metode yang dapat merangsang siswa untuk berpikir kritis dan realistis. Salah satu metode pembelajaran yang tepat untuk diterapkan metode pembelajaran kooperatif tipe Think Pair- Share (TPS) yang merupakan metode pembelajaran yang memberi kesempatam kepada siswa untuk berpikir, belajar sendiri dan bekerja sama dengan orang lain. Siswa termotivasi dalam menyelesaikan tugas-tugas Karena belajar dengan cara berkelompok sehingga dapat masuk untuk menyelesaikan materi Seni Budaya yang sulit dengan cara ini siswa dapat meningkatkan keterampilan siswa. keterampilan akan menunjukan tingkat yang maksimal, dapat memenuhi seorang pendidik menguasai metode dalam mengajar yang efektif dan Efesien sesuai dengan kriteria siswa, dan pada penelitian ini, penelitian mendapatkan kurang maksimalnya hasil belajar siswa selama ini.

kerja sama akademik antara siswa membentuk hubungan positif, mengembangkan rasa percaya diri serta meningkatkan kemampuan akademik aktivitas kelompok. Keunggulan lain dari pembelajaran ini adalah optimalisasi Partisipasi siswa. 
Tahapan-tahapan dan karakterisktik dari metode think pair share (TPS). maka metode pembelajaran ini dapat melatih beberapa karakter untuk dapat meningkatkan keterampilan siswa. Pada tahap berpikir dan pasangan karakter jujur dan tanggung jawab dapat dimunculkan melalui kejujuran siswa dalam tugas yang diberikan pada setiap tahapan dan tanggung jawab dalam menyelesaikan semua tugas yang diberikan. Pada tahap berbagi karakter yang muncul adalah tanggung jawab atas hasil unjuk kerja yang dilakukan dengan teman kelompoknya. Sedangkan karakter disiplin dapat dilihat pada saat ketepatan waktu dalam masuk kelas. Oleh karena itu, melalui metode think pair share (TPS) diharapkan dapat menanamkan karakterkarakter yang baik dalam diri siswa masingmasing, serta dapat meningkatkan kesadaran pribadi siswa untuk semangat belajar sehingga dengan demikian dapat meningkatkan keterampilan siswa.

Keberhasilan kelompok dalam ini merupakan hal yang utama. Dengan demikian dalam kelompok belajar, siswa yang kemampuan akademiknya tinggi ikut bertanggung jawab untuk membantu siswa yang kemampuan akademiknya rendah. Pembelajaran kooperatif menekankan pada kerja sama siswa sekaligus para siswa bertanggung jawab terhadap aktifitas belajar kelompok agar semua anggota kelompok dapat memahami materi pelajaran dengan baik.

Menurut Kamus Besar Bahasa Indonesia (KBBI), penerapan adalah penerapan penerapan, sedangkan menurut beberapa penerapan, penerapan adalah suatu penerapan mempraktekkan suatu teori, metode, dan hal lain untuk mencapai tujuan tertentu dan untuk suatu kepentingan yang diinginkan oleh suatu kelompok atau golongan yang telah terencana dan tersusun sebelumnya. Menurut Usman (2002: 24), penerapan (implementasi) adalah bermuara pada suatu aktivitas, aksi, tindakan, atau adanya suatu sistem.Implementasi bukan sekedar aktivitas, tetapi suatu kegiatan yang terencana dan untuk mencapai tujuan kegiatan. Menurut Setiawan (2004: 77) penerapan (implementasi) adalah perluasan aktivitas yang saling menyesuaikan proses interaksi antara tujuan dan tindakan untuk mencapainya serta memerlukan jaringan pelaksana, birokrasi yang efektif. Berdasarkan pengertian-pengertian tersebut dapat menunjukkan bahwa kata penerapan (implementasi) bermuara pada aktifitas, adanya aksi, tindakan, atau suatu sistem. Ungkapan from the name that of the application (implementasi) bukan sekedar aktifitas, tetapi suatu kegiatan yang terencana dan dilakukan secara sungguh-sungguh berdasarkan acuan norma tertentu untuk mencapai tujuan kegiatan.

Dalam buku yang disusun oleh Tim Pengembangan Ilmu Pendidikan FIP UPI (2007: 24) memaparkan bahwa peningkatan berasal dari kata tingkat yang berarti lapis atau lapisan dari sesuatu yang kemudian membentuk susunan. Tingkat dapat juga berarti pangkat, taraf dan kelas. Sedangkan peningkatan berarti peningkatan, peningkatan peningkatan derajat, dan peningkatan kuantitas. Peningkatan juga diartikan penambahan keterampilan dan kemampuan agar menjadi lebih baik. Selain itu rekaman dalam proses, ukuran, sifat, hubungan dan sebagainya.

Kata peningkatan juga dapat menggambarkan perubahan dari keadaan atau sifat yang berubah menjadi positif. Sedangkan hasil dari sebuah peningkatan dapat berupa kuantitas dan kualitas. Kuantitas adalah jumlah hasil dari sebuah proses. Sedangkan kualitas menggambarkan nilai dari suatu objek karena kejadian yang memiliki tujuan yang berupa peningkatan. Hasil dari suatu kebisingan dapat diperoleh dengan tercapainya suatu tujuan pada suatu titik tertentu. Dimana saat suatu usaha atau proses telah sampai pada titik tersebut maka perasaan puas dan bangga atas yang diharapkan.

Tari adalah suatu penampilan, jika anda suka, sesuatu yang aneh itu akan muncul secara tiba-tiba. la muncul dari apa yang dilakukan oleh para penari, namun apa yang secara fisik (penari) berada dihadapan anda berputar atau meliyukkan tubuhnya; apa yang anda lihat merupakan sebuah tontonan tentang kekuatankekuatan yang sering dapat dilihat, dengan demikian kelihatannya tarian itu dapat ditiru, digerakkan, dipindahkan, atau dikurangi (Hadi Sumandiyo, 2005: 23)

Tari Tari mengungkapkan diri melalui medium ungkapnnya, yaitu gerak (tenaga), ruang, dan waktu yang sebagai elemen dasar 
atau elemen estetis yang juga merupakan kekutannya (Hadi Sumandiyo, 2005: 25). Peneliti akan mengajarkan tari Nusantara yaitu tari panen. Namun yang akan mengajar yaitu guru yang mengajar oleh ibu Bau Salawati. Tari panen ini memiliki 6 ragam.

Keterampilan (skill) dalam arti yang tepat, kecepatan, dan ketepatan dalam tingkah laku motorik yang disebut juga skill normal. Sedangkan dalam arti luas, keterampilan termasuk aspek keterampilan normal, keterampilan intelektual, dan keterampilan sosial (Gunawan, 2011: 52). Keterampilan adalah pola kegiatan yang bertujuan, yang memerlukan manipulasi dan koordinasi informasi yang dipelajari (Sudjana, 1996: 17).

Keterampilan Menari Keterampilan adalah hasil belajar pada ranah psikomotorik, yang terbentuk dalam belajar hasil kognitif. Keterampilan adalah kemampuan untuk melaksanakan atau melaksanakan sesuatu dengan baik (Nasution, 1975: 28) Maksud dari pendapat tersebut bahwa kemampuan adalah kemampuan dan potensi yang dimiliki sescorang untuk menguasai suatu keahlian yang dimilikinya sejak lahir. Kemampuan tersebut merupakan suatu hasil latihan yang digunakan untuk melakukan sesuatu. Melalui opini di atas dapat dikatakan bahwa kemampuan seseorang dapat tumbuh melalui latihan-latihan yang dilakukan oleh orang itu sendiri.

Menari berasal dari kata tari yang berarti melakukan gerak tari. Sedangkan tari memiliki definisi definisi. Definisi tari menurut beberapa ahli yang ditulis oleh Kusnadi (2009: 1-2) di antaranya, (1) Tari adalah gerak ritmis (Curt Sachs). Gerak ritmis adalah gerak manusia yang sudah berolah tempo dan dinamikanya. Gerak ritmis kadang-kadang cepat, kadang-kadang patah-patah, kadangkadang-kadang; (2) Tari adalah gerak-gerak yang berbentuk dan ritmis dari badan di dalam ruang (Corrie Hartong); (3) Tari ekspresi adalah jiwa manusia yang melesat melalui gerak ritmis yang indah (Soedarsono). Tari menjadi sebuah sarana manusia untuk mengungkapkan perasaan, kehendak, atau pikiran manusia. Gerak dalam tari pesan yang tidak memiliki arti namun memiliki makna agar sesuatu yang akan tersampaikan dan dapat diterima oleh orang lain; dan (3) Tari adalah keindahan bergerak anggota-anggota badan manusia yang, berirama, berjiwa yang harmonis (Bagong Kusudiharjo).

Kesimpulan dari beberapa penjabaran di atas, tari adalah ekspresi jiwa manusia yang kesatuan gerak yang tertata, diselaraskan dengan irama, dan dilakukan dengan jiwa yang dalam. Gerak dalam tari adalah gerak yang diperindah dan disusun dengan baik untuk menciptakan harmonisasi dan keselarasan dengan irama. Dilakukan dengan penjiwaan akan makna yang terkandung dalam sebuah tarian. Berdasarkan pengertian tentang keterampilan dan menari yang telah dijabarkan, maka dapat ditarik kesimpulan bahwa keterampilan menari adalah kemampuan seseorang dalam melakukan gerak yang tertata dan diselaraskan dengan irama, serta dengan penjiwaan yang dalam dengan baik dan tepat. Keterampilan menari ditunjukkan dengan kemampuan melakukan gerak yang baik dan tepat dengan yang seharusnya dilakukan. Mampu bergerak sesuai dengan irama dalam tarian dan mampu mengekspresikan makna dan jiwa dalam tarian agar dapat dimengerti dan dinikmati penonton.

Menurut Hamdayama Jumanta ( 2015: 117) Tidak setiap metode dapat digunakan dalam setiap kompetensi dasar. Metode yang digunaka guru pembelajarannya, inovatif, menarik, tidak monoton serta mampu dengan kompetensi dasar yang ingin dicapai. Untuk membangkitkan atau motivasi belajar siswa yaitu mengguanakan cara atau metode dan media yang bervariasi, karena dengan metode dan media yang bervariasi dapat dihalangi.

Menurut Marwan Fausi (2014: 76) Metode think pair share (TPS) dapat membantu pendidik membantu dan mengendalikan kelas secara total, dan prosedur yang digunakan dalam metode think pair share (TPS) dapat memberi siswa lebih banyak waktu berpikir dalam memecahkan masalah, untuk menanggapi dan saling membantu.

Menurut Marwan Fausi (2014: 78) Metode think pair share (TPS) kepada siswa untuk memikirkan terlebih dahulu sebelum menilai dengan pasangannya dan diperagakan di depan kelas, belajar sendiri dan bekerja sama dengan orang lain. Siswa termotivasi dalam menyelesaikan tugas karena belajar dengan cara berpasangan. Siswa dapat menyatukan 
pendapat mereka sebelum masuk sehingga dapat masuk untuk menyelesaikan materi yang sulit dengan cara ini siswa dapat meningkatkan hasil belajar siswa. dengan seluruh kelas tentang apa yang telah didiskusikan. Ini yang efektif dilakukan dengan cara bergiliran demi pasangan dan hasil kerja sama telah mendapat kesempatan untuk melaporkan pekerjaannya.

Keunggulan dari teknik ini adalah optimalisasi Partisipasi siswa, yaitu memberi kesempatan delapan kali lebih banyak kepada setiap siswa untuk dikenali dan menunjukkan partisipasi mereka kepada orang lain. Selain itu, dapat diterapkan dalam matapelajaran apapun termasuk mata pelajaran praktek sepertiseni tari dan tentu saja disesuaikan dengan kondisi lingkungan serta ketika kegiatan belajar mengajar berlangsung.

Metode think pair share (TPS) menurut Ibnu Badar Trianto (2015: 112) merupakan suatu teknik sederhana. Metode think pair share (TPS) dapat meningkatkan kemampuan siswa dalam mengingat suatu informasi serta seseorang siswa dapat belajar dari siswa lain serta saling menyampaikan idenya untuk didiskusikan sebelum disampaikan didepan kelas. Metode think pair share (TPS) juga memperbaiki rasa percaya diri dan semua siswa diberi kesempatan untuk menilai dalam kelas Metode think pair share (TPS) sebagai salah satu metode pembelajaran kooperatif yang terdiri dari tiga tahapan, yaitu thinking, pairing, sharing Guru, tidak lagi sebagai satu-satunya sumber pembelajaran (Berorientasi guru), tetapi justru siswa dituntut untuk dapat menemukan dan memahami konsep-konsep baru (berorientasi siswa) .Sehingga bukan guru sebagai sumber pembelajaran tetapi juga siswa dapat menjadi patner belajar mengajar.

\section{METODE}

Penelitian ini menggunakan penelitian deskriptif kuantitatif dan kualitatif, dimana peneliti menggunakan metode deskriptif dengan pendekatan kuantitatif. Data yang diperoleh berupa-angka yang selanjutnya dijabarkan kedalam bentuk kalimat. Penelitian deskriptif adalah penelitian yang berusaha mendeskripsikan suatu gejala, peristiwa, kejadian yang terjadi pada saat sekarang (Suharsimi Arikunto, 2011: 64).
Tujuan penelitian adalah mendapatkan penjelasan tentang sejumlah kebermaknaan dalam model yang dihipotesiskan sebagai jawaban atas masalah yang telah dirumuskan.Karena pembuktian bersifat matematis, dalam penelitian kuantitatif perlu diperhatikan tiga hal yaitu pendefinisian, pengukuran- dan pengujian (Indrawan, 2014: 51). Desain penelitian pada hakikatnya merupakan strategi pembantuan penelitian dan dibuat sebagai kerangka acuan dalam melaksanakan penelitian. Desain yang digunakan dalam penelitian ini adalah penelitian tindakan kelas. Penelitian akan dilakukan melalui dua siklus pembelajaran yang memuat tahapan perencanaan, pelaksanaan, evaluasi, dan refleksi pada setiap siklus akhir.

Adapun skema siklus penelitian ini adalah sebagai berikut:

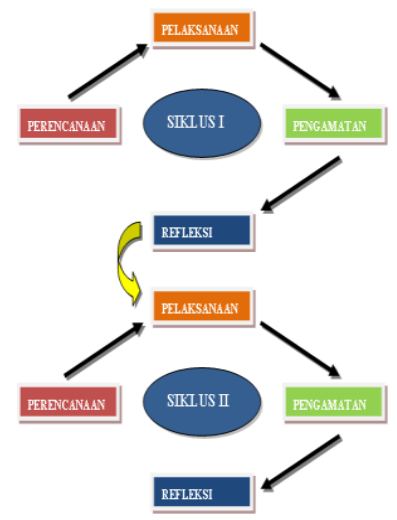

Gambar 1. Skema penelitian

Subyek penelitian ini adalah siswa kelas VIII E tahun ajaran 2019/2020 yang mungkin berjumlah 28 siswa. Tempat dan Waktu Penelitian Penelitian dilaksanakan di SMPN 14 Bulukumba pada Tahun ajaran 2019/2020. Penelitian dilakukan selama 1 bulan. Peneliti memilih tempat tersebut sebagai subjek penelitian karena sekolah tersebut memiliki masalah yang harus diberikan solusi pemecahaan masalah. Salah satu yang merupakan salah satu siswa yang kurang terampil dalam menari. Sehinggah peneliti tertantang untuk mencari solusi peningkatan keterampilan menari siswa dengan metode TPS Di SMP Negeri 4 Bulukumba. Teknik Pengumpulan Data dilakukan dengan Observasi dengan cara mengamati langsung terhadap objek yang diamati pada saat proses 
pembelajaran berlangsung.Wawancara adalah salah satu bentuk tehnik wawancara. Data yang banyak digunakan dalam penelitian deskriptif kualitaif dan deskriptif kuantitatif. Wawancara dilaksanakan secara lisan dalam pertemuan tatap muka secara individu. Oleh karena itu dalam wawancara, peneliti telah mempersiapkan instrumen berupa pertanyaanpertanyaan yang berkaitan dengan pelajaran budaya dan peneliti juga mewawancarai siswa mengenai kesulitan apa yang saat saat melakukan praktek tari. Wawancara dilakukan dengan narasumber pelaku siswa-siswa kelas VIII E SMPN 4 Bulukumba. Metode dokumentasi pada penelitian ini digunakan untuk mengumpulkan data yang bersumber dari arsip dan dokumen baik yang berada di luar sekolah, yang ada, dengan penelitian yang akan dilakukan. Dokumentasi pada penelitian ini digunakan untuk mengumpulkan data tentang pembelajaran teknik, pasangan berbagi untuk meningkatkan keterampilan menari siswa kelas VIII E di SMPN 4 . Tes Unjuk Kerja Tes adalah prosedur sistematik yang dibuat dalam bentuk tugas-tugas yang distandarisasikan dan diberikan kepada individu atau kelompok untuk dikerjakan, dijawab, atau direspon baik dalam bentuk tulisan, lisan, maupun perubahan. Jadi, tes yang akan dilakukan dalam penelitian ini adalah tes unjuk kerja atau tes praktek tari Panen melalui kegiatan pembelajran seni budaya untuk meningkatkan keterampilan siswa dalam menari. Studi Pustaka Untuk mencari konsep, teori dan juga informasi yang berhubungan dengan tulisan ini yang dapat dijadikan landasan penelitian, terlebih dahulu melakukan studi kepustakaan untuk menemukan literatur atau sumber bacaan yang dibutuhkan dalam melakukan penelitian.

Teknik Analisis Data Setelah data terkumpul, langkah selanjutnya adalah analisis data. Teknik analisis data dilakukan dengan menelaah seluruh data yang terkumpul dari berbagai sumber. Pengolahan dan analisis data dalam penelitian yaitu analisis data kuantitatif dan analisis data kualitatif. Tujuan penelitian kuantitatif adalah mendapatkan penjelasan tentang besarnya kebemaknaan dalam metode yang dihipotesiskan sebagai jawaban atas masalah yang telah dirumuskan. Karena pembuktian bersifat matematis, dalam penelitian kuantitatif perlu diperhatikan tiga hal yaitu pendefinisian, pengukuran, dan pengujian (Indrawan. 2014: 51).

Proses analisis data melalui tahapan yang dimulai dari proses penyusunan data dan analisis data dalam penelitian kualitatif dilakukan sejak memasuki lapangan, selama di lapangan, dan setelah selesai lapangan. Setelah penulis menganggap data yang telah menjawab cukup, langkah selanjutnya mengelompokkan data sesuai permasalahan penelitian dan kemudian dianalisis secara kuantitatif dengan menggunakan rumus sederhana.

Untuk mendapatkan nilai akhir yang dimiliki oleh siswa setelah dilakukan tindakan, maka dapat diketahui dengan menggunakan rumus:

$$
\mathrm{N}=\frac{\text { Jumlah nilai yang diperoleh }}{\text { Nilai Maksimal }} \times 100
$$

Keterangan:

$\mathrm{N}$ : Nilai akhir

Untuk mendapatkan nilai rata-rata yang dimiliki oleh siswa setelah dilakukan tindakan, maka dapat diketahui dengan menggunakan rumus:

$$
\text { Skor rata-rata }=\frac{\text { Total Skor }}{\text { Total Siswa }}
$$

Untuk mendapatkan presentase nilai keseluruhan yang dimiliki oleh siswa setelah dilakukan tindakan, maka dapat diketahui dengan menggunakan rumus: jumlah siswa keseluruhan

Keterangan :

$\mathrm{P}=$ Persentase rata - rata penilaian

HASIL DAN PEMBAHASAN

1. Data Awal 
Pada kondisi awal Keterampilan Menari terhadap pembelajaran seni Pada Kelas VIII E di SMPN 4 Bulukmba Mellui Penerapan Metode Think Pair Share dilakukan dengan 2 siklus. Namun sebelum menerapkan Siklus I peneliti telah melakukan observasi untuk melihat dan menjadikan perbadingan hasil yang nantinya peneliti dapatkan. Pada saat observasi awal peneliti melihat nilai siswa kelas VIII E sangat rendah dalam pembelajaran seni budaya khususnya tari. Berdasarkan hasil wawancra dan observasi peneliti sebelum melaksankan penelitian

Berikut nilai keterapilan siswa dalam menari sebelum dilakukan tindakan.

Fatur Rahman: 85 tuntas, Fitrah: 25 tidak tuntas, Hasriandi: 78 tuntas, Marsah: 83 tuntas, Muh. Ardan: 25 tidak tuntas, Muh. Rasul: 80 tuntas, Nur Citra Kirana: 80 tuntas, Nur Fainnah: 85 tuntas, Rahmadani. H: 25 tidak tuntas, Rahmawati: 60 tidak tuntas, Rasul Aditya Putra: 79 tuntas, Rehan: 25 tidak tuntas, Rehan Rhamadan: 85 tuntas , Rezkyawan: 77 tuntas, Riska Yulianti: 77 tuntas, Safira Irawan: 82 tuntas, Saiful: 85 tuntas, Sakina Muslimin: 77 tuntas, Sindi: 25 tidak tuntas, Syahrul. S: 30 tidak tuntas, Tiara: 30 tidak tuntas, Ikbal: 65 tidak tuntas, Sulkifli: 63 tidak tuntas, Mifta Lubis : 75 tuntas, Mirnawati: 25 tidak tuntas, Nurul Mutia : 25 tidak tuntas, Musnidah: 53 tidak tuntas, Asrul Sani: 85.

\section{Peningkatan Keterampilan Menari Melalui Penerapan Metode Think Pair Share( TPS) Pada Kelas VIII E di SMP Negeri 4 Bulukumba}

Dari tes unjuk kerja ini mengacu pada tiga aspek yang dilakukan berupa keterampilam gerak (wiraga), harmonisasi gerak dengan iringan musik (wirama), dan penghayatan atau penjiwaan dalam gerak (wirasa). Setelah siswa melakukan aktivitas menari bersama kelompoknya maka dilakukan sebuah tes unjuk kerja untuk mengukur kemampuan siswa dalam melakukan gerak tari, Dalam melakukan tes unjuk kerja dimulai langsung oleh guru dengan panduan lembar tes unjuk kerja. Tes yang dilakukan yaitu siswa melakukan gerak tari Panen secara berkelompok di depan guru. Pelaksanaan tes ini dilakukan dua kali setelah setiap pelaksanaan metode pembelajaran kooperatif tipe Think Pair Share pada siklus I dan siklus II sebagai akhir dari setiap siklus.

\section{Indikator Penilaian}

1. Skor sangat kurang

a. aspek wiraga

Jika siswa tidak mampu melakukan sesuai patokan, meliputi volume gerak, kekuatan, keseimbangan, kecepatan, atau kelenturan dengan baik dan benar atau hanya mampu melakukan salah satu dari patokan yang ada. Jika siswa mampu melakukan gerak sesuai.

b. Aspek wirasa

Jika siswa tidak mampu menghayati dan mengekspresikan ekspresi dengan mimik wajah yang baik dan benar.

c. Aspek wirama

Jika siswa tidak memahami iringan dan tidak mampu memeragakan bahasa sesuai dengan iringan yang tepat.

2. Skor kurang

a. aspek wiraga

Jika siswa mampu melakukan gerak sesuai dengan dua atau tiga patokan, meliputi volume gerak, kekuatan, keseimbangan, kecepatan, atau kelenturan dengan baik dan benar.

b. Aspek wirasa

Jika siswa belum mampu menghayati dan mengekspresikan diri dengan mimik wajah dengan baik, namun sudah memahami isi cerita dan belum percaya diri.

c. Aspek wirama

Jika siswa kurang mampu melakukan gerak sesuai iringan dan masih belum mampu melakukan pergerakan dengan tepat. 
3. Skor cukup

a. aspek wiraga

Jika siswa hanya mampu

melakukan gerak sesuai dengan sebagian besar patokan meliputi volume gerak, kekuatan, keseimbangan, kecepatan, dan kelenturan dengan baik dan benar

b. Aspek wirasa

Jika siswa mampu memahami isi cerita tarian, mampu mekspresikan tarian dengan mimik wajah namun belum masih belum percaya diri atau belumkosisten

c. Aspek wirama

Jika siswa mampu melakukan gerak sesuai dengan iringan mapu memahami tanda-tanda perpindahan gerak naun belum mampu melakukan perpindahan gerak yang tepat

4. Skor Baik

a. Aspek wiraga

Jika siswa mampu melakukan gerak sesuai dengan patokan meliputi volume gerak, kekuatan, keseimbangan, kecepatan, dan kelunturan dengan baik dan benar.

b. Aspek wiraga

Jika siswa mampu menghayati tarian dengan iringan dan dengan percaya diri mampu mengeekspresikan tarian dengan mimik wajah.

c. Aspek wirama

Jika siswa mampu melakukan gerak sesuai dengan iringan dan mampu melakukan perpindahan gerak dengan tepat.

Menunjukkan bahwa hasil pengukuran keterampilan menari siswa mampu mencapai nilai rata-rata 72,8 . Berdasarkan nilai prasiklus dari 28 siswa yang mengikuti proses latihan, untuk kategori sangat baik dengan rentang nilai 85-100 dicapai oleh 13 siswa atau 46\%, Kategori baik dengan rentang nilai 71-85 dicapai oleh enam orang siswa atau $22 \%$, kategori cukup dengan rentang nilai 56-70 tidak ada siswa yang mencapai skor tersebut. Sedangkan untuk kategori kurang dengan rentang nilai 55 dicapai oleh sembilan orang siswa atau $32 \%$ dari jumlah siswa.

\section{Penerapan Metode Think Pair Share( TPS) yang dapat Berkontribsi terhadap Upayah peningkatan keteramilan menari siswa kelas VIII E di SMP Negeri Bulukumba}

Penggunaan metode mengajar yang sesuai dengan materi yang akan mempengaruhi keterampilan siswa menari sehingga berpengaruh terhadap hasil belajar. Dalam penerapannya, langkah-langkah dalam penggunaan metode pembelajaran kooperatif ini terdiri dari beberapa tahap yaitu sebagai berikut: 1) Tahap persiapan, dimana pada tahap ini, ada beberapa hal yang dilakukan, antara lain merumuskan tujuan yang harus dicapai oleh siswa, menentukan dengan je las keterampilan spesifik dan berurutan, menentukan rangkaian gerakan atau langkah yang harus dikerjakan untuk menghindari kesalahan, 2) Tahap pelaksanaan dimana dalam tahap ini terdiri dari tiga langkah yaitu langkah pembukaan dimana beberapa hal yang perlu dilaksanakan oleh guru di antaranya: (a) mengemukakan tujuan yang harus dicapai, bentuk-bentuk latihan yang akan dilakukan. (b) langkah pelaksanaan seperti memulai latihan dengan hal-hal yang sederhana dulu, menciptakan suasana yang menyenangkan, meyakinkan bahwa semua siswa tertarik untuk ikut dan memberikan kesempatan kepada siswa untuk terus berlatih. (c) melangkahi langkah yang diberikan bahwa

\begin{tabular}{|l|l|l|l|l|l|l|}
\hline No & Kategori & $\begin{array}{l}\text { Rentang } \\
\text { nilai }\end{array}$ & Frekuensi & Bobot skor & Presentase(\%) & $\begin{array}{l}\text { Nilai rata }- \\
\text { rata }\end{array}$ \\
\hline 1 & Sangat baik & $86-100$ & 13 & 1260 & 46 & \multirow{2}{*}{$\frac{2040}{28}$} \\
2 & Baik & $71-85$ & 6 & 474 & 22 & 72,8 \\
\hline 3 & Cukup & $56-70$ & 0 & 0 & 0 & \\
\hline 4 & Kurang & $\leq 55$ & 9 & 306 & 32 & \\
\hline
\end{tabular}
etiap diet sudah selesai, maka harus terus 
memberikan motivasi untuk siswa yang terus melakukan latihan secara berkesinambungan sehingga latihan yang diberikan dapat semakin melekat, terampil dan terbiasa, 3) Penutup melaksanakan perbaikan terhadap kesalahan kesalahan-kesalahan yang dilaksanakan oleh siswa dan memberikan latihan penenangan. Penerapan metode pembelajaran kooperatif sangat mendukung hasil penelitian yang diperoleh. Metode tersebut digunakan dalam mempraktekkan suatu keterampilan (seni tari).

Hasil penelitian di atas menunjukkan, metode pembelajaran kooperatif disinyalir sebagai suatu stimulus yang baik untuk mengoptimalkan keterampilan atau kemampuan yang dimiliki siswa dalam pembelajaran tari di sekolah.

Proses metode pembelajaran kooperatif menjadikan: 1) Bahan pelajaran yang diberikan dalam suasana yang sungguh-sungguh akan lebih kokoh tertanam dalam daya ingat siswa, perasaan, kemauan dikonsentrasikan pada pelajaran yang ada, 2) siswa akan dapat menggunakan daya pikirannya dengan bertambah baik, karena yang sehat maka siawa akan menjadi lebih teratur, teliti dan mendorong daya ingatnya, 3) Adanya pengawasan, bimbingan dan koreksi yang segera dari guru, memungkinkan siswa untuk melakukan kesalahan saat itu juga.

Hal ini dapat meningkatkan waktu belajar disanping, siswa dapat melihat prestasinya. Pengaruh positif yang muncul pada pembelajaran dengan metode pembelajaran kooperatif adalah: 1) Siswa mampu memperoleh kecakapan motorik yaitu keterampilan dalam menari tari Panen, 2) Siswa mampu memperoleh kecakapan mental dalam menari tari Panen, 3) Siswa mampu memperoleh kecakapan dalam bentuk asosiasi, 4) kebiasaan terbentuknya yang dilakukan dan menambah ketépatan serta kecepatan pelaksanaan, 5) Pemanfaatan kebiasaan yang tidak memerlukan konsentrasi dalam pelaksanaan, 6) Pembentukan kebiasaankebiasaan menjadikan gerakan-gerakan yang kompleks, rumit, menjadi lebih otomatis.

\section{Peningkatan keterampilan menari siswa setelah penerapan Metode Think Pair Share (TPS) pada kelas VIII E di SMP Negeri 4 Bulukumba}

Peningkatan keterampilan keterampilan siswa setelah penerapkan metode pembelajaran kooperatif tipe Think PairShare telah menggunakan lembar observasi di siklus pertama menunjukkan bahwa respons siswa terhadap pelajaran sudah mengalami peningkatan nilai penilaian dari beberapa butir indikator dari tahap sebelumnya tahap prasiklus sebelum diterapkan model pembelajaran ini. Hal ini terbukti bahwa siswa aktif mengikuti kegiatan pembelajaran tari ini. Dan juga dapat dilihat dari hasil tes dimana mulai dari siklus I, dan siklus II rata-rata dan presentasi yang mereka peroleh setiap tahapnya peningkatan peningkatan pada siswa.

Berdasarkan rekapitulasi dari hasil produksi, keterampilanmenari siswa dengan menerapkan metode pembelajaran kooperatif tipe Think Pair Sharepada siklus I, siklus II mengalami peningkatan. Hasil penilaian keterampilan menari siswa dalam siklus I mencapai nilai rata-rata 72,8 . Dengan rincian sebutkan 13 orang siswa atau $46 \%$ mencapai nilai sangat baik, enam orang siswa atau $22 \%$ mencapai nilai baik, tidak ada satupum siswa yang mencapai nilai dengan kategori cukup, sembilan orang siswa atau $320 \%$ nilai dengan kategori kurang. Hasil keterampilan menari siswa pada siklus Il mencapai nilai rata-rata 92,3 dengan rincian sebanyak 21 orang siswa atau $75 \%$ mencapai nilai dengan kategori sangat baik.tujuh orang siswa atau $25 \%$ mencapai nilai kategori baik sedangkan kategori cukup dan kurang ada siswa yang mencapai nilai tersebut. Berdasarkan hasil tersebut menunjukkan bahwa tingkat percaya siswa dalam meningkatkan keterampilan menari pada siklus II mengalami peningkatan sebanyak $90 \%$ sehingga mampu mencapai nilai dengan kategori baik dan sangat baik.

Metode pembelajaran yang diterapkan oleh peneliti penerapan metode pembelajaran kooperatif tipe Think Pair Shareharus lebih banyak memungkinkan siswa belajar melalui proses, dengan tujuan yang mampu terus berkembang karena kebiasaan yang dilakukan oleh siswa mampu mewujudkan suatu peningkatan yang signifikan sehingga apa yang telah diberikan oleh peneliti berdasarkan materi ajar, mampu diterima baik oleh siswa. Pembelajaran dapat berjalan dengan baik jika interaksi yang tidak dimaksud hanya satu arah dari peneliti kepada siswa saja, melainkan 
interaksi dua arah yakni peneliti dengan siswa, dan siswa dengan siswa lainnya.

\section{SIMPULAN DAN SARAN}

Berdasarkan hasil analisis data dan pembahasan dapat ditarik sebagai berikut:

1. Upayah Meningkatkan Keterampilan Menari Siswa melalui Penerapan Metode Think Pair Share (TPS) pada Kelas VIII E di SMP Negeri 4 Bulukumba dapat meningkatkan prestasi belajar siswa kelas VIII E di SMPN 4 Bulukumba dengan penggunaan siklus 1 dan II. Hal ini terbukti secara empiris pada nilai rata-rata di siklus I sebanyak 72,8 sedangkan di siklus II nilai rata-rata yang diperoleh sebanyak 92,3

2. Melalui Penerapan Metode Think Pair Share (TPS) yang dapat Berkonstribusi terhadap Upayah peningkatan Keterampilan menari Siswa Kelas VIl E di SMP Negeri 4 Bulukumba dilaksanakan sebanyak II Siklus karena pada Siklus 1 belum mencapai KKM sehinggah dilaksanakanlah Siklus II, setelah diberikan tindakan dengan tambahan metode pendekatan untuk membantu dan meningkatkan keterampilan siswa kelas VIII E di SMPN 4 Bulukumba dalam pembelajaran seni tari. Hal ini terbukti secara empiris bahwa sebelum penerapan tindakan hanya $40 \%$ yang terampil dan setelah pelaksanaan tindakan meningkat menjadi $90 \%$.

Sedangkan saran berdasarkan hasil penelitian maka dapat diajukan saran-saran sebagai berikut:

1. Kepada guru mata pelajaran seni tari, agar mencoba menerapkan metode tink Phair Sherere untuk menciptakan suasana pembelajaran yang menyenangkan.

2. Kepada guru mata pelajaran seni tari, agar mencoba menerapkan metode think phair share dalam kelas sehinggah siswa tidak merasa sungkan untuk bertanya jika tidak mengerti.

\section{DAFTAR RUJUKAN}

Arikunto, S. 2011. Prosedur Penelitian (Suatu Pendekatan Praktik). Jakarta: Rineka Cipta

Dimyati. 2005. Belajar dan Pembelajaran. Jakarta: Rineka Cipta

Gunawan. 2011. Sosiologi Pendidikan. Jakarta : Rineka Cipta

Hadi, S. 2005. Kajian Tari Teks dan Konteks. Pustaka PT. Blisiller

Hamdayama, J. 2014. Metode dan Metode Pembelajaran Kreatif dan Berkarakter. Bogor: PT Ghalia Indonesia.

Triyanto, I.B. 2015. Mendesain Metode Pembelajaran Inovatif, Progregrif, dan Kontektual. Jakarta: Prenadamedia Grop.

Kusnadi. 2009. Seni Budaya. Jakarta: Global

Indrawan, R. 2014. Metode Penelitian. Bandung: Refika Aditama.

Marwan, F. 2014. Penerapan Metode Think Pair Shara (TPS) Terhadap Hasil Belajar Seni Budaya Siswa Kelas VII SMP Lampung. FBS. Universitas Semarang.

Nasition. 1975. Sejarah Pendidikan Indonesia. Bandung: Mujur.

Noor, J. 2015. Metodologi Penelitian. Jakarta: Prenadamedia

Rafiaka, Tia. 2012. Peningkatan Keterampilan Menari Dengan Metode Pembelajaran Kooperatif Tipe Think Pair Share (TPS) Pada Siswa Kelas VII Di SMP Negeri 2 Sawangan Kabupaten Magelang. Skripsi. Fakultas Bahasa dan Seni Universitas Negeri Yogyakarta.

Sudjana. 1996. Penilaian Hasil Proses Belajar Mangajar. Bandung: CV Jaya.

Soedarsono. 2010. Seni Pertunjukan Indonesia di Era Globalisasi. Penerbit: Gadjah Mada University Press

Sachs, Curt. 2010. World History of The Dance. Penerbit: The Norton Library 
Setiawan. 2004. Penelitian Tinsdakan Kelas (Action Reasearch). Jakarta: RT Raja Grafindo Persada. 